\title{
TREATMENT OF SPOROTRICOSE IN THE WORLD, WITH EMPHASIS IN BRAZIL: WHAT'S NEW?
}

Lucas Gonçalves Mesquita de Oliveira ${ }^{1 *}$, Karina Mika Kameoka', Gustavo de Oliveira Alves Pinto', Amanda Lins Bispo Monteiro', Marina Luiza Nascimento Rocha', Daniela Maria Bastos de Souza ${ }^{2}$

1UFRPE; ${ }^{2}$ DMFA: Departamento de Morfologia e Fisiologia Animal - UFRPE

\section{ABSTRACT}

Objective: To evaluate the in vitro and in vivo results of works already published on the use of traditional and alternative medicines in the treatment of sporotrichosis, both in humans and in animals. Methods: The bibliographic research was developed from the analysis of publications found in the scientific literature, with emphasis mainly on Brazil in the period from 2015 to 2020 . Updated bibliographies of the medical and veterinary literature were available on MEDLINE, through PubMed, Science direct, Scielo and academic Google, with a total of 28 studies that met the specific work requirements. Results: From the analysis of the reviewed papers, conventional treatments, mainly the use of itraconazole, Amphotericin B and Terbinafine, showed good results in the studies. In addition, the use of alternative treatments, either as the main treatment or support, against sporotrichosis, have shown promise in vitro results, requiring more tests for a possible alternative treatment in the future. Conclusion: The use of alternative treatments is important, since they can be effective against sporotrichosis, becoming a viable means when the animal is resistant to conventional methods.

Keywords: Sporothrix, Alternative treatments, Antifungal
*Correspondence to Author: Lucas Gonçalves Mesquita de Oliveira

UFRPE

How to cite this article:

Lucas Gonçalves Mesquita de Oliveira, Karina Mika Kameoka, Gustavo de Oliveira Alves Pinto, Amanda Lins Bispo Monteiro, Marina Luiza Nascimento Rocha, Daniela Maria Bastos de Souza.TREATMENT OF SPOROTRICOSE IN THE WORLD, WITH EMPHASIS IN BRAZIL: WHAT'S NEW?.International Journal of Traditional and Complementary Medicine 2021, 6:36.

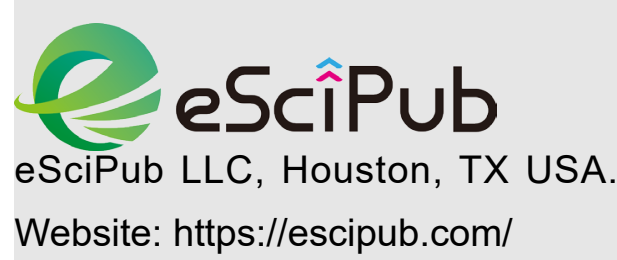




\section{INTRODUCTION}

Sporotrichosis is an infectious disease caused by dimorphic fungi of the genus Sporothrix, which can be classified as cutaneous, cutaneous lymphatic, disseminated cutaneous, mucous and systemic [1]. It is an emerging disease in tropical and subtropical regions, being considered the most common subcutaneous mycosis in Latin America. In Brazil, it is considered the main expanding zoonosis when analyzed in the eyes of epidemiology [2]. In the country's south and southeast, more precisely in Rio de Janeiro, São Paulo and Rio Grande do Sul, are concentrate the largest number of reported cases of sporotrichosis, the Sporothrix schenckii as the most prevalent etiological agent. This is due to the high population density and the poor condition of hygiene and basic sanitation, associated with the high number of abandoned animals [3]. From 2015 to 2017, in Rio de Janeiro, approximately 1097 suspected cases of sporotrichosis were reported, with an average close to $60 \%$ confirmed, and by May 2018, 319 suspected cases, with $69 \%$ confirmed [4]. In 2019, 242 were suspected cases, with $88.4 \%$ [214] confirmed [5].

The mycosis has been reported in several animal species, such as the dog, cat, horse, donkey, mule, cattle, chimpanzees, armadillos, camels, poultry, and dolphins, in addition to man. The cats have greater sensitivity in presenting the most severe form of the disease, compared to other species. The highest reported incidence is in non-castrated males, with access to the street [6,7], this disease has a high zoonotic character, and the greatest parasitic load found, are in cutaneous lesions of felines, becoming the biggest source of fungus infection, by scratches, bites or living with sick cats [8].

The choice of antifungal for the treatment of sporotrichosis is based on the clinical presentation of the disease, the etiologic agent involved and the host's immune status. In general, in Brazil, four drugs are more common in the treatment of sporotrichosis, these being
Itraconazole, Amphotericin B, Terbinafine and Potassium lodide. Conventional treatment for infected humans and animals begins with the use of an azole derivative, itraconazole, which acts directly on the permeability of the fungal cell membrane. Some drugs are in common use of the treatment of sporotrichosis in humans are not part of the conventional treatment routine in veterinary medicine, such as Amphotericin B, Posaconazole and candinas, thus reducing the therapeutic options. Other interventions have been studied for the genus Sporothrix spp. [9].

Due to negative factors of the most usual drugs and emphasizing resistance of these conventional antifungals from clinical isolates of Sporothrix spp., there was a need for new research for alternative treatments. Noteworthy are the studies with botanical species that have potential applicability in the pharmaceutical industry against pathogenic fungi, due to the richness and complexity of secondary metabolites, isolated and/or synthesized substances and new vaccine prospects, all aiming a promising result in reducing the fungal load.

Aiming the contributing scientifically and add knowledge to assist in conducting therapy, this review intends to describe recent studies on alternative treatments for pathogenic species Sporothrix schenckii and Sporothrix schenckii complex.

\section{METHODS}

The present work was based on the analysis of publications found in the literature on conventional and alternative treatments for worldwide sporotrichosis, from 2015 to 2020. Updated bibliographies of the literature available in the electronic databases MEDLINE [National Library of Medicine], USA], through PubMed, Science direct, Scielo [Scientific Electronic Library Online] and academic Google, using the following terms: "Alternative treatments", "Treatments", "Sporotrichosis" and "Case reports" "Sporothrix". The English terms were: "Sporotrichosis", "treatment", "Sporothrix" and "therapeutic vaccines". 
The selection of publications was restricted to articles with innovative treatments and conventional and case reports to prove the effectiveness of the treatments found, focusing on the species S. Schenckii and brasiliensis. Among the articles found in electronic databases, 28 met specific work requirements. Articles with repeated information about treatments with positive results were excluded.

\section{RESULTS AND DISCUSSION}

\section{ALTERNATIVE PERSPECTIVES- WHAT'S NEW? \\ THERAPEUTIC}

There is an aggravating factor related to the use of itraconazole, with the emergence of refractory species of the Sporothrix spp. resistant to this drug, which stimulates research on alternative therapies that are promising to combat sporotrichosis [9].

Currently, several studies involving botanical species have been presented, species of the Lamiaceae family are highlighted as promising for antifungals due to their chemical composition. In recent years, plant extracts of some species have in vitro proven for strains of S. brasiliensis, such as extracts from Origanum majorana and Rosmarinus officinalis [11], Camellia sinensis [12], in addition to the commercial extract of propolis from Apis mellifera [13]. As for isolates of $S$. schenckii , we have reports of studies with ethanol extract from Vismia guianeses [14], the consumption's relationship of Allium sativum L. [24], Origanum vulgare and Rosmarinus officinalis [28]. In addition to extracts, essential oils such as $O$. majorana [16], R. officinalis Linn. e O. vulgare [17] were tested for $S$. brasiliensis and for the $S$. schenckii complex.

Research lines on prophylactic therapy aimed at immunizing sporotrichosis are also reported. According to Fuentes et al., 2015, the formulation $\mathrm{AH}$ [Aluminum Hydroxide] + CWP100, proved to be a candidate for the vaccine for generating an immune response in the tests performed, requiring additional tests. A study involving $S$. Schenckii CW proteins
[SsCWP] formulated with Montanide Gel Pet A and aluminum hydroxide, promoted a protective antibody response associated with the immune response after vaccination with these vaccines with adjuvants [18].

Studies of the association of some substances with conventional antifungals seeking the synergy of agents have been published, such as the use of ibuprofen associated with other antifungals, which has been shown to be effective in reducing concentrations and inhibiting fungal growth. [19]. For strains of $S$. brasiliensis, the associations of diphenyl diselenide [PhSe-organic selenium compound] were tested alone or combined with itraconazole [ITC], suggesting that both forms may be potential alternative therapy [20], as well as Clotrimazole alone or combined with itraconazole [21].

Analyzes against $S$. schenckii strains are also reported. The effect of terpinen-4-ol [T-OH] against the $S$. schenckii complex alone or combined was described by Brilhante et al.,[2019], where the combinations of $\mathrm{T}-\mathrm{OH}$ with itraconazole or terbinafine were synergistic. The fungicidal activity of Curcurmina [CUR] has been reported in mice infected against $S$. schenckii where a synergistic effect of CUR with terbinafine [TRB] is described as a potential antifungal agent. The inhibition of biofilm with filamentous and yeast forms of the $S$. schenckii complex has been reported as promising with research with chitosans [22] and the use of potassium iodite with Miltefosina [23].

In the synthesis of compounds, Pentathiepin analogs showed a more potent response than the ITC [24] and the chelators deferiprone [DFP] and ethylenediaminetraacetic acid [EDTA] reduced the growth of planktonic cells of Sporothrix spp. and had synergistic interaction with antifungal drugs against this pathogen reducing the formation of biofilm. The synthesis of two $\alpha$ - and $\beta$-2,3- dihydrofuranaptoquinone compounds [compounds 6 and 10] are potential candidates for the development of new antifungal agents in the treatment of 
sporotrichosis, as they have shown good antifungal activity and stability y[25]. In genetic engineering, the humanized gp70 Antigen [mAbP6E7] was able to opsonize S. schenckii yeasts and decrease the fungal load in vivo. This data suggest that humanized P6E7 may have a therapeutic role in sporotrichosis [26].

\section{CONCLUSION}

It was observed, therefore, that many studies with alternative treatments have been carried out in the last five years, and that most of them presented a favorable result in the treatment against Sporothrix schenckii and brasiliensis. The importance of these is related to the wide variety of antifungal properties and the resistance acquired by the fungus when using conventional treatments, such as itraconazole, and consequently in the control of disease outbreaks.

\section{REFERENCES}

1. Fuentes DLP, Batista-Duharte A, Ferreira LS, Martínez DT, Polesi MC, Duarte RA, et al. A cell wall protein-based vaccine candidate induce protective immune response against Sporothrix schenckii infection. Immunobiology [Internet]. 2016;221[2]:300-9.

2. Orofino-Costa $R$, Rodrigues $A M$, de Macedo PM, Bernardes-Engemann AR. Sporotrichosis: An update on epidemiology, etiopathogenesis, laboratory and clinical therapeutics. An Bras Dermatol. 2017;92[5]:606-20.

3. Gremião IDF, Miranda LHM, Reis EG, Rodrigues AM, Pereira SA. Zoonotic Epidemic of Sporotrichosis: Cat to Human Transmission. PLoS Pathog. 2017;13[1]:2-8.

4. Almeida $P$, Giordano C. Vigilância e cenário epidemiológico: esporotricose no estado do RJ. Bol Epidemiológico Esporotricose. 2018;001:16.

5. Giordano $C$, Almeida $P$, Santana $A$, Inês $M$. Cenário epidemiológico: esporotricose no estado do RJ. Bol Epidemiológico Arboviroses [Internet]. 2019;001:1-6.

6. Gonçalves JC, Gremião IDF, Kolling G, Duval AE de A, Ribeiro PMT. Esporotricose, o gato e a comunidade. Cent científico Conhecer. 2019;16[29]:769-87.

7. Schubach TM, Menezes RC, Wanke B. Esporotricose. In: Doenças Infeciosas em cães e gatos. 2015. p. 678-84.

8. De Souza EW, De Moraes Borba C, Pereira SA, Gremião IDF, Langohr IM, Oliveira MME, et al. Clinical features, fungal load, coinfections, histological skin changes, and itraconazole treatment response of cats with sporotrichosis caused by Sporothrix schenckii . Sci Rep. 2018;8[1]:1-10.

9. Rosa CS da, Meinerz ARM, Osório LDG, Cleff MB, Meireles MCA. Terapêutica Da Esporotricose: Revisão. Sci Anim Heal. 2018;5[3]:212.

10. Waller SB, Cleff MB, Serra EF, Silva AL, Gomes $A$ dos R, de Mello JRB, et al. Plants from Lamiaceae family as source of antifungal molecules in humane and veterinary medicine. Microb Pathog [Internet]. 2017;104:232-7.

11. Waller SB, Madrid IM, Hoffmann JF, Picoli T, Cleff MB, Chaves FC, et al. Chemical composition and cytotoxicity of extracts of marjoram and rosemary and their activity against Sporothrix schenckii . J Med Microbiol. 2017;66[7]:1076-83.

12. Waller SB, Madrid IM, Serra EF, Dos Reis Gomes A, Cleff MB, De Faria RO. In vitro susceptibility of the Sporothrix schenckii to aqueous extracts of the green tea [Camellia sinensis L. Kuntze]. Acta Vet Bras. 2015;9[4]:342-7.

13. Waller SB, Peter CM, Hoffmann JF, Picoli T, Osório $L$ da $G$, Chaves $F$, et al. Chemical and cytotoxic analyses of brown Brazilian propolis [Apis mellifera] and its in vitro activity against itraconazole-resistant Sporothrix schenckii . Microb Pathog [Internet]. 2017;105:117-21.

14. Oliveira $A H$, de Oliveira GG, Carnevale Neto F, Portuondo DF, Batista-Duharte A, Carlos IZ. Anti-inflammatory activity of Vismia guianensis [Aubl.] Pers. extracts and antifungal activity against Sporothrix schenckii. J Ethnopharmacol [Internet]. 2016;195:266. 0

15. Burian JP, Sacramento LVS, Carlos IZ. Controle da infecção fúngica pelos extratos de alho [Allium sativum L.] e modulação da atividade de macrófagos peritoneais em modelo murino de esporotricose. Brazilian J Biol. 2017;77[4]:84855.

16. Waller SB, Madrid IM, Ferraz V, Picoli T, Cleff $\mathrm{MB}$, de Faria RO, et al. Cytotoxicity and antiSporothrix schenckii activity of the Origanum majorana Linn. oil. Brazilian J Microbiol [Internet]. 2016;47[4]:896-901.

17. Waller SB, Madrid IM, Cleff MB, Santin R, 
Freitag RA. Effects of essential oils of Rosmarinus officinalis Linn. and Origanum vulgare Linn. from different origins on Sporothrix schenckii and Sporothrix schenckii complex. Arq Bras Med Veterinária e Zootec. 2016;68[4]:991-9.

18. Portuondo DL, Batista-Duharte A, Ferreira LS, de Andrade CR, Quinello C, Téllez-Martínez D, et al. Comparative efficacy and toxicity of two vaccine candidates against Sporothrix schenckii using either Montanide ${ }^{\mathrm{TM}}$ Pet Gel $\mathrm{A}$ or aluminum hydroxide adjuvants in mice. Vaccine [Internet]. 2017;35[34]:4430-6.

19. Borba-santos LP, Nucci M, Ferreira-Pereira A, Rozental S. Anti- Sporothrix activity of ibuprofen combined with antifungal. Soc Bras Microbiol. 2020;1-7.

20. Poester VR, Mattei AS, Mendes JF, Klafke GB, Ramis IB, Sanchotene KO, et al. Antifungal activity of diphenyl diselenide alone and in combination with itraconazole against Sporothrix schenckii . Med Mycol. 2019;57[3]:328-31.

21. Gagini T, Borba-Santos LP, Rodrigues AM, de Camargo ZP, Rozental S. Clotrimazole is highly effective in vitro against feline Sporothrix schenckii isolates. J Med Microbiol. 2017;66[11]:1573-80.

22. Garcia LGS, de Melo Guedes GM, Fonseca XMQC, Pereira-Neto WA, Castelo-Branco DSCM, Sidrim JJC, et al. Antifungal activity of different molecular weight chitosans against planktonic cells and biofilm of Sporothrix schenckii . Int $\mathrm{J}$ Biol Macromol [Internet]. 2020;143:341-8.

23. Brilhante RSN, Silva MLQ Da, Pereira VS, De Oliveira JS, Maciel JM, Silva ING Da, et al. Potassium iodide and miltefosine inhibit biofilms of Sporothrix schenckii species complex in yeast and filamentous forms. Med Mycol. 2019;57[6]:464-72.

24. Asquith CRM, Machado ACS, de Miranda LHM, Konstantinova LS, Almeida-Paes R, Rakitin OA, et al. Synthesis and identification of pentathiepin-based inhibitors of Sporothrix schenckii . Antibiotics. 2019;8[4]:1-12.

25. Garcia Ferreira $P$, Pereira Borba-Santos L, Noronha LL, Deckman Nicoletti C, de Sá Haddad Queiroz M, de Carvalho da Silva F, et al. Synthesis, Stability Studies, and Antifungal Evaluation of Substituted $\alpha$ - and $\beta-2,3-$ Dihydrofuranaphthoquinones against Sporothrix schenckii and Sporothrix schenckii. Molecules. 2019;24[5].
26. de Almeida JRF, Santiago KL, Kaihami GH, Maranhão $A Q$, Brígido $M$ de $M$, de Almeida SR. The efficacy of humanized antibody against the Sporothrix antigen, gp70, in promoting phagocytosis and reducing disease burden. Front Microbiol. 2017;8[MAR]:1-9.

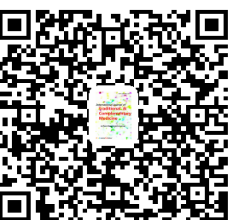

IJTCM: https://escipub.com/international-journal-of-traditional-and-complementary-medicine/ 